\title{
PEMETAAN ASET PENGHIDUPAN PETANI DALAM MENGELOLA HUTAN RAKYAT DI KABUPATEN GUNUNGKIDUL \\ (The Farmer Livelihood Asset Mapping on Community Forest Management in Gunungkidul District)
}

\author{
Silvi Nur Oktalina ${ }^{1,2 *}$, San Afri Awang ${ }^{3}$, Slamet Hartono ${ }^{4}$ dan Priyono Suryanto ${ }^{3}$ \\ ${ }^{1}$ Sekolah Vokasi, Universitas Gadjah Mada, Sekip Yogyakarta 55281. \\ ${ }^{2}$ Program Doktor Ilmu Kehutanan, Fakultas Kehutanan, Universitas Gadjah Mada, \\ Bulaksumur Yogyakarta 55281. \\ ${ }^{3}$ Fakultas Kehutanan, Universitas Gadjah Mada, Bulaksumur Yogyakarta 55281. \\ ${ }^{4}$ Fakultas Pertanian, Universitas Gadjah Mada, Bulaksumur Yogyakarta 55281. \\ *Penulis korespondensi. Tel: 08164228414. Email: silvi.nuroktalina@ugm.ac.id.
}

Diterima: 13 Mei 2015

Disetujui: 1 September 2015

\begin{abstract}
Abstrak
Petani dalam mengelola sumberdaya alam memerlukan aset. Aset penghidupan petani (sumberdaya manusia, sumberdaya alam, finansial, fisik dan sosial) sangat berpengaruh terhadap pencapaian tujuan penghidupan. Penelitian ini bertujuan untuk mengukur level aset penghidupan yang digunakan petani dalam mengelola hutan rakyat. Pendekatan penelitian dengan survei di 6 desa di Kabupaten Gunungkidul yaitu Nglanggeran, Katongan, Dengok, Sodo, Girimulyo dan Jepitu. Jumlah responden di setiap desa 30 orang, sehingga total responden adalah 180 petani. Penentuan responden dalam penelitian ini dilakukan secara random. Teknik skoring dengan pembobotan digunakan untuk mengukur level aset yang digunakan petani dalam mengelola hutan rakyat berdasarkan pada Multicriteria Analysis (MCA). Hasil penelitian menunjukkan bahwa petani hutan rakyat di zona Batur Agung (bagian utara Gunungkidul) menggunakan aset berdasarkan prioritasnya yaitu aset sumberdaya manusia, sosial, sumberdaya alam, fisik dan finansial. Urutan penggunaan aset petani di zona Ledok Wonosari (bagian tengah) adalah aset sosial, sumberdaya manusia, finansial, fisik dan sumberdaya alam. Bagi petani di zona Pegunungan Seribu prioritas penggunaan aset adalah aset fisik, finansial, sosial, sumberdaya manusia dan sumberdaya alam.
\end{abstract}

Kata kunci: aset, hutan rakyat, penghidupan, petani, sumberdaya alam.

\begin{abstract}
Farmers manage natural resources require asset. Farmer livelihood assets (human resources, natural resources, financial, physical and social) greatly affect to the achievement of the livelihood objectives. The objective of this study is to measure the level of livelihood assets used by farmers in managing community forests. Data collected by survey in 6 village in Gunungkidul i.e. Nglanggeran, Katongan, Dengok, Sodo, Girimulyo and Jepitu village by interviewing 30 respondents each village, so the total respondents are 180 respondents. Weighted scoring technique used to measure the level of assets used by farmers in managing community forests based on Multicriteria Analysis (MCA). The results showed that the community forest farmers in Batur Agung zone (The northern part of Gunungkidul) using the asset based on its priority: human resource asset, social, natural resources, physical and financial. While the priority asset of farmers in Ledok Wonosari (middle of Gunungkidul) are social assets, human resources, financial, physical and natural resources. For farmers in Pegunungan Seribu (The South part of Gunungkidul) priority assets that used are physical assets, financial, social, human resource and natural resources.
\end{abstract}

Keywords: asset, community forest, farmer, livelihood natural resources.

\section{PENDAHULUAN}

Manusia memerlukan modal/aset untuk mencapai tujuan penghidupannya. Aset penghidupan merupakan aset yang ternilai maupun yang tidak ternilai berupa materi maupun sosial yang dipergunakan manusia untuk menyelenggarakan penghidupan (Krantz, 2001). Dalam menyelenggarakan penghidupan, aset yang dibutuhkan tidak hanya satu macam. Untuk itu akan diperlukan kombinasi aset-aset yang ada supaya dapat meningkatkan kesejahteraan masyarakat. Jenis aset yang lebih bermanfaat atau mendukung bagi penghidupan seseorang adalah berbeda-beda pada tiap individu. Department for International Development (DFID) mengidentifikasi 5 kategori aset yang digunakan untuk penghidupan, yaitu sumberdaya manusia, sumberdaya alam, sumberdaya finansial, sumberdaya fisik dan sumberdaya sosial (Anonim, 1999). 
Aset penghidupan dapat digambarkan dalam bentuk pentagon. Pentagon yang terbentuk dari aset tersebut menunjukkan variasi seseorang atau masyarakat dalam mengakses aset. Kusters dkk. (2005) mengindentifikasi aset dalam 3 skala, yaitu pada level keluarga, masyarakat dan negara. Pada level keluarga dipilih indikator untuk menilai bagaimana suatu produk berkontribusi pada aset keluarga. Pada level masyarakat indikator yang digunakan adalah bagaimana pengaruhnya terhadap aset masyarakat secara umum. Pada level nasional indikator yang digunakan misalnya pendapatan dari ekspor, serapan tenaga kerja maupun pendapatan dari pajak. Aset penghidupan adalah faktor penting yang perlu diungkap dan dipahami dengan tepat karena setiap sumberdaya memiliki karakteristik dan daya dukung yang berbeda bagi penghidupan setiap individu dan masyarakat.

Setiap sumberdaya memiliki hubungan atau keterkaitan dengan sumberdaya yang lain. Kabijakan dan program pembangunan yang efektif memperhatikan dan memetakan dengan tepat sumberdaya mana yang menjadi prioritas dalam suatu program dan sumberdaya mana yang perlu mendapatkan dukungan. Hal ini memerlukan kearifan lingkungan dari para pemangku kepentingan. Kearifan lingkungan dapat berupa kearifan sosial dalam bentuk tatanan sosial yang menciptakan keharmonisan dan kedinamisan hidup masyarakat yang telah dijalani secara turun temurun dan menunjukkan adanya manfaat yang diterima oleh masyarakat setempat dalam membangun peradabannya (Nuraini dkk., 2015). Kesalahan yang sering terjadi adalah suatu program cenderung eksploitatif terhadap sumberdaya tertentu dan kurang memperhatikan pengembangan sumberdaya lain sebagai alternatif.

Pemetaan aset penghidupan dilakukan dengan melihat potret aset yang digunakan untuk penghidupan pada saat itu. Pemetaan aset dapat menggambarkan dinamika antar aset secara individu maupun kolektif pada waktu tertentu dan kontribusinya terhadap penghidupan (Jakobsen, 2013). Kombinasi aset yang digunakan akan menentukan bentuk pentagon, sehingga melalui pemetaan aset akan dapat diketahui akses terhadap suatu aset tertentu dalam suatu aktivitas penghidupan. Dengan mengetahui level akses aset yang digunakan maka akan dapat ditentukan tindakan selanjutnya untuk menyusun strategi penghidupan sehingga tujuan penghidupan dapat tercapai.

Pengelolaan hutan rakyat oleh masyarakat menggunakan aset yang berbeda-beda. Penggunaan jenis dan level aset yang berbeda berpengaruh terhadap intensifikasi pengelolaan hutan rakyat yang berdampak pada kelestarian hutan rakyat dan penghidupan petani. Dengan demikian identifikasi jenis dan level aset yang digunakan petani dalam pengelolaan hutan menjadi penting untuk dilakukan. Penelitian ini mendeskripsikan macam-macam aset yang digunakan oleh petani dalam pengelolaan hutan hutan rakyat sehingga dapat diketahui bentuk pentagon dari setiap wilayah lokasi penelitian. Melalui bentuk pentagon aset maka dapat dianalisis level penggunaan aset oleh petani dalam mengelola hutan rakyat untuk meningkatkan penghidupannya. Pengukuran aset dalam mengelola hutan rakyat menjadi sangat penting karena hutan rakyat mempunyai beberapa kelebihan. Salah satu kelebihan sistem hutan rakyat adalah keanekaragamanhayati dalam ekosistem ini lebih tinggi dibandingkan hutan tanaman, selain itu jenis tanamannya mempunyai nilai ekonomi tinggi untuk daerah setempat (Ethika dkk., 2014). Penelitian ini bertujuan untuk mengukur level aset penghidupan yang digunakan oleh petani dalam mengelola hutan rakyat.

\section{METODE PENELITIAN}

\section{Waktu dan Lokasi}

Penelitian ini dilaksanakan dalam 2 tahap, yaitu tahap I, bulan Januari-Maret 2013 dan tahap II, bulan Januari-Maret 2014. Lokasi penelitian adalah Kabupaten Gunungkidul. Kabupaten Gunungkidul (Gambar 1) berdasarkan kondisi geomorfologi di bagi menjadi 3 zona, yaitu zona Batur Agung (bagian utara), Zona Ledok Wonosari (bagian tengah) dan Zona Pegunungan Seribu (bagian selatan). Dari ketiga zona tersebut selanjutnya dipilih 6 desa sampel secara random. Desa yang menjadi lokasi penelitian adalah Desa Nglanggeran Kecamatan Patuk dan Desa Katongan Kecamatan Nglipar di Zona Batur Agung, Desa Dengok Kecamatan Playen dan Desa Sodo Kecamatan Paliyan di Zona Ledok Wonosari, Desa Jepitu Kecamatan Girisubo dan Desa Girimulyo Kecamatan Purwosari.

\section{Prosedur Penelitian Pengumpulan data}

Metode dasar yang digunakan dalam penelitian ini adalah survei. Survei dilakukan dengan mengambil responden petani hutan rakyat secara acak. Jumlah responden yang diambil dalam pengukuran aset ini adalah 30 orang responden setiap desa, sehingga total jumlah responden adalah 180 orang responden. Untuk kepentingan verifikasi data dan melengkapi data survei juga dilakukan wawancara secara mendalam dengan tokoh-tokoh kunci yang paham dan mengerti tetang pengelolaan hutan rakyat di Kabupaten Gunungkidul. 


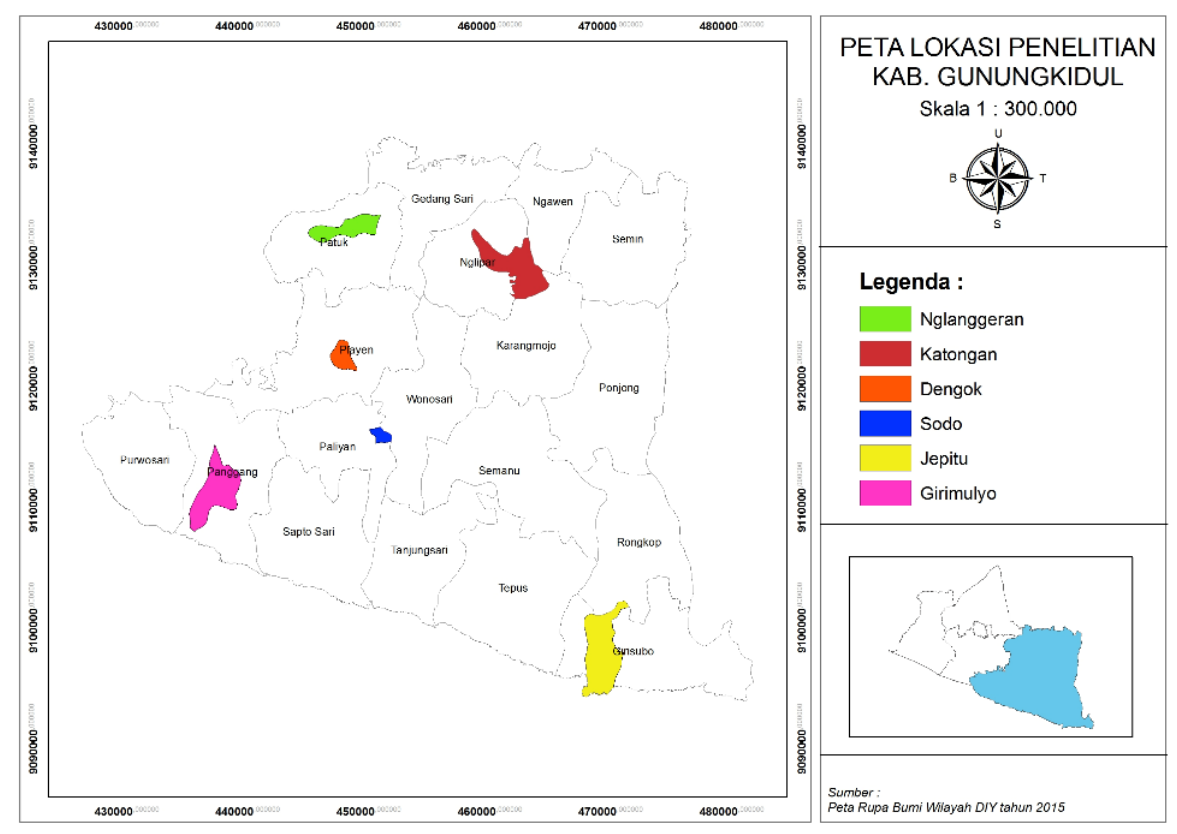

Gambar 1. Lokasi penelitian.

\section{Analisis data}

Analisis data dilakukan dengan menggunakan metode statistik deskriptif. Tabel, diagram dan distribusi frekuensi akan digunakan untuk menyajikan data. Selanjutnya data tersebut diintepretasi dan dijabarkan secara deskriptif sehingga dapat lebih bermakna. Teknik scoring digunakan untuk mengukur aset yang paling dominan dimiliki oleh masyarakat yang selanjutnya divisualisasikan dengan menggunakan diagram radar pentagon. Setiap variabel selanjutnya diberi pembobotan, ukuran bobot diverifikasi kepada masyarakat untuk menyesuaikan dengan kondisi yang sebenarnya di lokasi penelitian. Dari setiap jawaban dalam kuisioner selanjutnya dilakukan diberikan skor.

Analisis data yang dilakukan dengan berpedoman pada multikriteria analisis (Multicriteria Analysis/MCA). MCA adalah alat yang dikembangkan untuk pengambilan keputusan yang dibangun dari multi kriteria yang kompleks baik secara kuantitatif maupun kualitatif (Mendoza, 1999). Hasil dari pengukuran aset yang digunakan petani dalam mengelola hutan rakyat disajikan dalam diagram pentagon, sehingga dapat dilihat aset yang paling dominan digunakan petani dan perbandingan antar aset. Dengan melihat diagram pentagon tersebut maka bentuk-bentuk intervensi yang dapat dilakukan untuk meningkatkan peran hutan rakyat dalam penghidupan dapat direncanakan.

\section{HASIL DAN PEMBAHASAN}

Aset meliputi ketersediaan dan aksesibilitas masyarakat terhadap sumberdaya yang mampu mendukung dan meningkatkan kondisi penghidupan masyarakat. Kemampuan untuk memperoleh strategi sumber penghidupan di antaranya tergantung pada kepemilikan sumberdaya alam, fisik, sosial dan ekonomi. Dengan demikian, sumber penghidupan dapat dilihat sebagai aset dasar dari berbagai sumber penghidupan yang akan dibangun oleh setiap individu. Oleh karena itu, skala prioritas ketersediaan sumberdaya sebagai aset pada suatu masyarakat pada suatu daerah tertentu akan berbeda dengan daerah lainnya. Perbedaan prioritas ketersediaan sumberdaya ini diperoleh dari literatur dan melalui wawancara mendalam dengan masyarakat.

Pengukuran aset yang digunakan petani untuk mengelola hutan rakyat dalam penelitian ini dibatasi pada 5 jenis, yaitu aset sumberdaya manusia, aset sumberdaya alam, aset fisik, aset finansial dan aset sosial (Anonim, 1999). Setiap aset diukur berdasarkan pada variabel-variabel pengukur aset berdasarkan pada literatur yang tersedia. Variabel pengukur setiap aset disajikan dalam Tabel 1 . Variabel pengukur setiap aset tersebut selanjutnya dijabarkan dalam kuisioner yang diberikan pada responden.

Hasil perhitungan pengukuran aset petani yang digunakan untuk mengelola hutan rakyat selanjutnya disajikan dalam Tabel 2. Hasil perhitungan dari aset yang digunakan petani untuk mengelola hutan rakyat selanjutnya dipetakan dalam bentuk diagram pentagon aset. Penggambaran aset petani dalam mengelola hutan rakyat di bedakan di setiap zona. Hal ini dilakukan karena kondisi geomorfologi setiap zona berbeda. Perbedaan geomorfologi membawa konsekuensi pada kondisi biofisik lahan yang berbeda sehingga budaya masyarakat yang ada di setiap zona juga berbeda karena menyesuaikan diri dengan kondisi alam yang ada di sekitarnya. 
Tabel 1. Variabel pengukur asset petani dalam mengelola hutan rakyat.

\begin{tabular}{|c|c|c|}
\hline Jenis aset & Variabel & Indikator \\
\hline $\begin{array}{l}\text { Sumberdaya } \\
\text { manusia }\end{array}$ & $\begin{array}{l}\text { - } \text { Tenaga kerja keluarga } \\
\text { - } \text { Pendidikan } \\
\text { - Keterampilan } \\
\text { - Kesehatan keluarga }\end{array}$ & $\begin{array}{l}\text { - Jumlah tenaga kerja produktif keluarga } \\
\text { - Latar belakang pendidikan kepala keluarga, jumlah } \\
\text { anggota keluarga yang minimal lulus SMA } \\
\text { - } \quad \text { Pengetahuan dan keterampilan kehutanan yang dimiliki } \\
\text { - Jumlah dan frekuensi anggota keluarga yang sakit bera }\end{array}$ \\
\hline $\begin{array}{l}\text { Sumberdaya } \\
\text { alam }\end{array}$ & $\begin{array}{l}\text { - Kepemilikan lahan (milik) } \\
\text { - Tipe penggunaan lahan } \\
\text { - } \text { Akses terhadap sumber daya alam } \\
\text { - Konflik pemanfaatan sumber daya } \\
\text { alam }\end{array}$ & $\begin{array}{l}\text { - Luas lahan milik dan lahan garapan } \\
\text { - Jumlah tipe lahan yang digarap } \\
\text { - Jumlah dan jenis sumberdaya alam yang dapat diakses } \\
\text { - Jumlah dan frekuensi konflik pemanfaatan SDA }\end{array}$ \\
\hline Finansial & $\begin{array}{l}\text { - Sumber dan jumlah pendapatan } \\
\text { - Tabungan keluarga } \\
\text { - Akses kredit } \\
\text { - Tingkat kecukupan finansial }\end{array}$ & $\begin{array}{l}\text { - Sumber-sumber dan jumlah pendapatan, persentase } \\
\text { pendapatan dari hutan } \\
\text { - Jumlah dan jenis tabungan yang dimiliki } \\
\text { - Jumlah sumber kredit yang dapat diakses } \\
\text { - Perbandingan antara pendapatan dan pengeluaran }\end{array}$ \\
\hline Fisik & $\begin{array}{l}\text { - Kepemilikan rumah } \\
\text { - } \text { Kepemilikan kendaraan } \\
\text { - } \text { Tingkat aksesibilitas lahan } \\
\text { Alat produksi }\end{array}$ & $\begin{array}{l}\text { - Kualitas rumah } \\
\text { - Jenis kendaraan yang dimiliki } \\
\text { - Sarana ke lahan } \\
\text { - Jumlah dan jenis alat produksi serta kemudahan } \\
\text { mengaksesnya }\end{array}$ \\
\hline Sosial & $\begin{array}{l}\text { - Jaringan } \\
\text { - Tingkat kepercayaan } \\
\text { - Norma-norma } \\
\text { - Sanksi-sanksi } \\
\end{array}$ & $\begin{array}{l}\text { - Jumlah organisasi kehutanan yang diikuti, tingkat } \\
\text { - } \quad \text { Tinghadiran dan partisipasi } \\
\text { - } \text { yang mepercayaan pada organisasi, jumlah lembaga } \\
\text { - Tingkat kepatuhan terhadan } \\
\text { - Tingkat kepatuhan terhadap sanksi }\end{array}$ \\
\hline
\end{tabular}

Tabel 2. Rekapitulasi skor aset petani dalam mengelola hutan rakyat.

\begin{tabular}{|c|c|c|c|c|c|}
\hline \multirow{2}{*}{ Desa } & \multicolumn{5}{|c|}{ Jenis aset } \\
\hline & Sumberdaya manusia & Sumberdaya alam & Finansial & Fisik & Sosial \\
\hline \multicolumn{6}{|c|}{ Batur Agung (Zona utara) } \\
\hline Nglanggeran & 11,3 & 10,7 & 9,2 & 10,8 & 11,0 \\
\hline Katongan & 12,0 & 10,3 & 8,6 & 9,6 & 11,2 \\
\hline \multicolumn{6}{|c|}{ Ledok Wonosari (Zona tengah) } \\
\hline Dengok & 9,5 & 8,9 & 10,4 & 10,4 & 10,2 \\
\hline Sodo & 10,8 & 9,6 & 9,4 & 8,9 & 11,7 \\
\hline \multicolumn{6}{|c|}{ Pegunungan Seribu (Zona selatan) } \\
\hline Jepitu & 9,0 & 9,2 & 12,1 & 12,2 & 9,7 \\
\hline Girimulyo & 10,8 & 9,8 & 8,9 & 9,4 & 11,2 \\
\hline
\end{tabular}

Sumber: Data primer (2014).

\section{Pemetaan Aset di Zona Batur Agung}

Pegunungan Batur Agung berbentuk cekungan dangan bagian utara merupakan dataran tinggi yang melintang dari Barat sampai ke Timur dan pada sebelah agak barat melengkung ke selatan. Topografi wilayah pegunungan Batur Agung sebagian besar berupa pegunungan lereng terjal dengan kemiringan hingga $>45 \%$. Kedalaman air tanah pada daerah ini mencapai $20 \mathrm{~m}$. Pegunungan ini mencakup 5 kecamatan, yaitu Kecamatan Patuk, Gedangsari, Nglipar, Ngawean dan Semin. Wilayah ini merupakan perbukitan dengan litologi dan struktur geologi agak kompleks dengan materi penyusun breksi vulkasin, atau pasir dan batu gamping. Kedalaman air tanah pada wilayah ini mencapai $25 \mathrm{~m}$.
Gambar 2 menunjukkan bahwa dalam mengelola hutan rakyat, petani di wilayah utara Kabupaten Gunungkidul lebih dominan menggunakan aset sumberdaya manusia. Hal tersebut dapat dilihat dari nilai skor yang paling tinggi dibandingkan dengan aset-aset yang lain. Aset sumberdaya manusia meliputi pengetahuan, keterampilan dan kemampuan untuk mengusahakan kehidupannya. Pengembangan kualitas manusia sangat menentukan, karena manusia yang akan mengelola aset untuk digunakan dan dilestarikan keberlanjutnnya (Scoones, 1998). Wilayah utara Kabupaten Gunungkidul mempunyai infrastruktur yang sudah bagus sehingga akses ke luar daerah untuk mendapatkan pendidikan lebih mudah. Masyarakat di wilayah utara Kabupaten Gunung- 


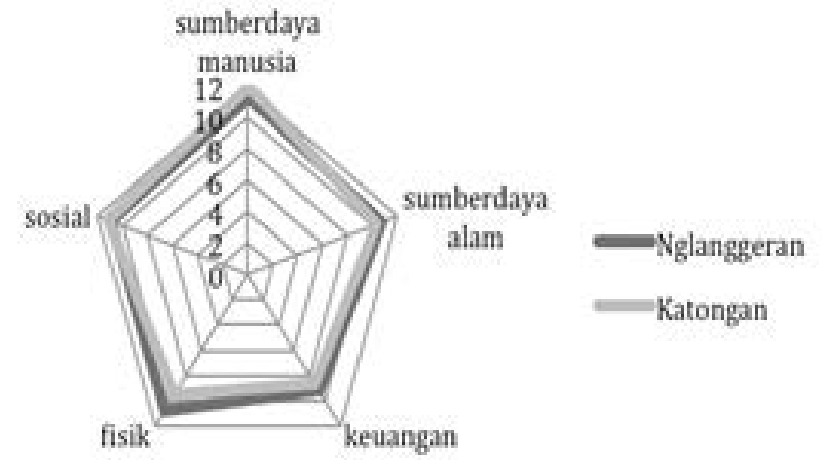

Gambar 2. Diagram pentagon aset petani di Pegunungan Baturagung.

Kidul mempunyai perhatian yang tinggi terhadap pendidikan dan keterampilan terutama pada generasi muda.

Aset yang mempunyai skor tinggi selanjutnya adalah aset sosial. Aset sosial merupakan kekuatan untuk mengusahakan penghidupan melalui jejaring dan keterkaitan sosial seperti gotong-royong, kepercayaan dan kekerjasama yang saling menguntungkan (Scoones, 1998). DFID mendeskripsikan aset sosial diidentifikasi dari 3 komponen, yaitu jaringan baik secara vertikal maupun horizontal, keanggotaan terhadap organisasi formal yang diukur dari diterimanya peraturan, norma dan sanksi, kepercayaan. Aset sosial yang digunakan dalam hal ini meliputi jaringan, kepercayaan, norma dan peraturan serta sanksi (Anonim, 1999).

Hutan sebagai bagian dari sumberdaya alam sangat berperan dalam kehidupan masyarakat terutama dalam mengaplikasikan nilai budaya dalam kehidupan masyarakat (Nurhadi dkk., 2012; Salosa dkk., 2014). Di wilayah utara Kabupaten Gunungkidul wilayah kawasan hutan yang dikelola negara dan masyarakat cukup luas sehingga aset sumberdaya alam merupakan aset yang juga menjadi prioritas petani. Infrastruktur dan sarana produksi yang merupakan aset fisik menjadi urutan penggunaan aset selanjutnya. Urutan terakhir penggunaan aset dalam mengelola hutan rakyat adalah aset finansial. Pada masyarakat pedesaan dalam pengelolaan hutan rakyat, uang seringkali mempunyai fungsi yang sangat kecil, karena pengelolaan hutan dilakukan secara gotong royong oleh para petani sehingga mengurangi biaya yang dikeluarkan.

\section{Pemetaan Aset di Zona Ledok Wonosari}

Di zona tengah Kabupaten Gunungkidul/ Ledok Wonosari yang mempunyai kesuburan tanah yang lebih tinggi dibandingkan dengan kedua zona yang lain dengan stok air yang lebih banyak menunjukkan bahwa petani lebih dominan menggunakan modal

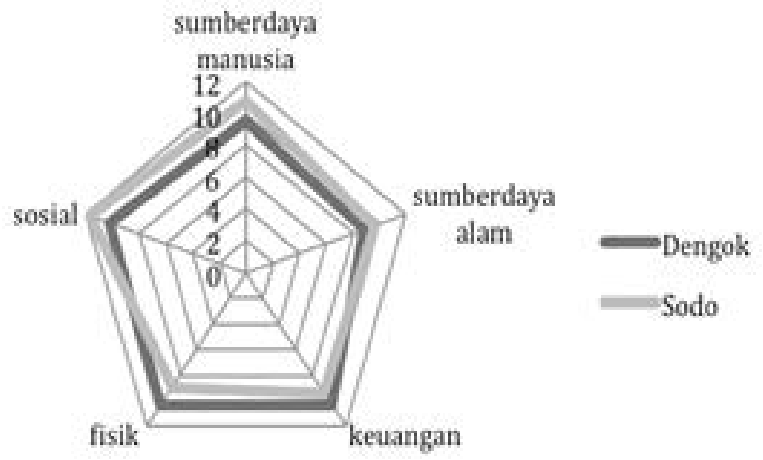

Gambar 3. Diagram pentagon aset petani di Ledok Wonosari.

sosial dibandingkan dengan aset yang lain. Wilayah Ledok Wonosari membentang luas di bagian tengah dengan lebar $15 \mathrm{~km}$ sepanjang utara selatan. Wilayah ini dicirikan dengan topografi yang rata kecuali di beberapa daerah yang berbatasan dengan satuan fisiografis lain dicirikan topografi bergelombang. Kedalaman air tanah pada wilayah ini adalah 10-15 m. Wilayah yang termasuk dalam wilayah Ledok Wonosari adalah Kecamatan Playen, Paliyan, Wonosari, Karangmojo, Ponjong Barat dan Semanu.

Di wilayah Ledok Wonosari penggunaan aset yang dominan dalam mengelola hutan rakyat adalah aset sosial. Hal ini dapat dilihat pada Tabel 2 yang menunjukkan skor paling tinggi dan Gambar 3 . Wilayah Ledok wonosari mempunyai karakter daerah pedesaan, yang mempunyai sifat-sifat mengutamakan kepentingan umum dibandingkan kepentingan pribadi. Aset sosial mempunyai peran penting dalam menjaga sumberdaya alam untuk kelestarian penghidupan (Jele, 2012). Aset sosial yang digunakan petani dalam mengelola hutan rakyat termasuk di dalamnya adalah kelembagaan kelompok tani yang menjadi wadah bagi para petani berorganisasi. Kelembagaan adalah kumpulan nilai, norma, peraturan dalam suatu kumpulan orang yang digunakan untuk mencapai tujuan tertentu (Awang, 2005).

Penggunaan aset selanjutnya dalam mengelola hutan rakyat di wilayah Ledok Wonosari adalah aset sumberdaya manusia, finansial, fisik dan sumberdaya alam. Wilayah Ledok Wonosari merupakan pusat pemerintahan dan perekonomian Kabupaten Gunungkidul sehingga didukung oleh sumberdaya manusia yang cukup tinggi. Aset sumberdaya manusia sangat diperlukan untuk menggunakan atau menggerakan aset-aset yang lain (Anonim, 1999). Kuantitas aset sumberdaya manusia terlihat dari ketersediaan jumlah tenaga kerja keluarga. Ketersediaan jumlah tenaga kerja keluarga dapat didekati dari jumlah anggota keluarga (Diggennaro, 2010). Jumlah anggota 
keluarga yang banyak maka tidak perlu menggunakan tenaga kerja di luar keluarga yang akan berdampak pada biaya produksi yang lebih besar. Sementara itu kualitas ketersediaan sumberdaya manusia dapat dilihat dari level kesehatan anggota keluarga (Jele, 2012).

Ledok Wonosari yang menjadi pusat kegiatan ekonomi mengakibatkan nilai uang menjadi lebih berarti dibandingkan dengan wilayah Pegunungan Batur Agung. Pengelolaan hutan rakyat di Ledok Wonosari sebagian juga telah dilakukan secara intensif sehingga banyak input yang mulai dibeli oleh petani, misalnya penggunaan bibit unggul, pupuk dan pemeliharaan tegakan hutan rakyat yang memerlukan tenaga kerja di luar keluarga.

Aset fisik menjadi prioritas selanjutnya karena petani sudah sadar bahwa pemasaran hasil hutan rakyat sangat penting untuk dilakukan. Untuk mendukung pemasaran tersebut maka infrastruktur menjadi sangat penting. Hal tersebut sesuai dengan yang disampaikan Anonim (1999), aset fisik adalah infrastruktur dasar dan barang-barang yang diperlukan untuk mendukung penghidupan. Selain infrastruktur, aset fisik juga meliputi kepemilikan peralatan dan saran prasarana untuk kegiatan produksi. Dalam kontek kewilayahan dapat berupa infrastruktur jalan, irigasi maupun akses terhadap informasi dan komunikasi (Scoones, 1998). Infrastruktur yang dimaksud adalah barang publik yang dapat diakses oleh semua orang tanpa biaya. Keberadaan aset fisik sangat penting bagi penghidupan karena akan memperlancar akses dan transportasi sarana dan prasarana produksi. Apabila transportasi tersebut tidak didukung infrastruktur yang baik maka akan meningkatkan biaya produksi.

Aset sumberdaya alam merupakan aset yang paling sedikit skornya. Aset sumberdaya alam merupakan aliran sumberdaya alam yang digunakan untuk penghidupan masyarakat (Anonim, 1999). Aset sumberdaya alam terkait dengan kepemilikan atau penguasaan sumberdaya alam seperti lahan, tanaman dan air sebagai asset produksi (Scoones, 1998). Mengingat sifatnya yang sulit dirubah maka petani dalam menggunakan sumberdaya alam sesuai dengan kepemilikannya. Penggunaan aset sumberdaya alam sangat penting terutama untuk kegiatan penghidupan yang berbasiskan alam, misalnya pertanian, kehutanan, peternakan maupun perikanan. Di antara aset sumberdaya alam yang paling penting bagi petani di Gunungkidul adalah kepemilikan lahan. Kepemilikan lahan dapat menjadi jaminan keamanan keluarga (Jele, 2012). Lahan dapat dijual sehingga menghasilkan uang atau digunakan untuk aktivitas produksi sehingga menghasilkan pendapatan lahan juga dapat

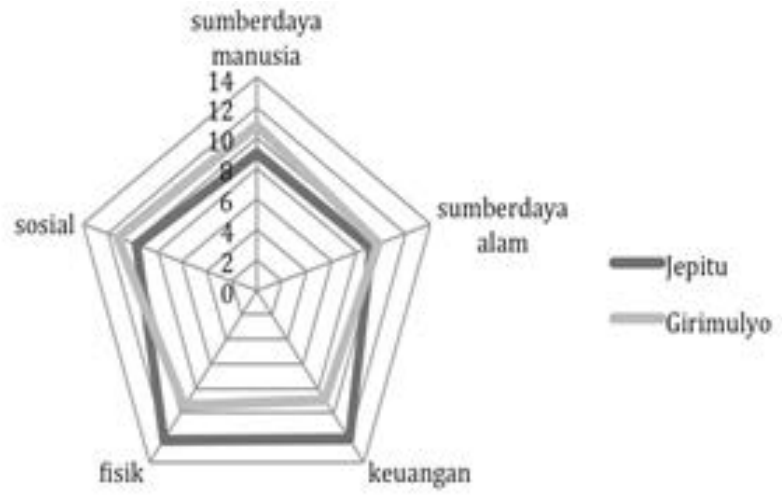

Gambar 4. Diagram pentagon asset petani di Pegunungan Seribu.

digunakan sebagai jaminan untuk mendapatkan pinjaman uang dari lembaga keuangan.

Penguatan aset sumberdaya alam dapat dilakukan dengan mengkonservasi dan menjaga kelestarian sumberdaya alam, menerapkan sistem provisi terhadap eksploitasi sumberdaya alam dan kegiatan-kegiatan tidak langsung misalnya dengan reformasi organisasi, penegakan peraturan yang terkait dengan eksploitasi sumberdaya alam (Anonim, 1999).

\section{Pemetaan Aset di Zona Pegunungan Seribu}

Pegunungan seribu merupakan wilayah topografi yang dicirikan oleh batuan penyusunnya berupa batu gamping. Topografi di wilayah ini berbukit-bukit kecil dan lereng terjal dengan lembah-lembah sempit tanpa aliran keluar di antara bukit-bukit tersebut. Wilayah yang termasuk dalam pegunungan Seribu adalah Kecamatan Purwosari, Panggang, Paliyan, Saptosari, Tanjungsari, Tepus, Semanu, Ponjong, Garbosari dan Kecamatan Rongkop. Wilayah di zona selatan didominasi kart dengan kondisi biofisik yang relatif beragam. Hal tersebut berimplikasi pada aset yang digunakan petani dalam mengelola hutan rakyat. Petani di wilayah Pegunungan Seribu lebih dominan menggunakan aset fisik dibandingkan dengan asetaset yang lain. Berdasarkan data Tabel 2 dan Gambar 4, urutan penggunaan aset di wilayah Ledok Wonosari setelah aset fisik adalah aset finansial, sosial, sumberdaya manusia dan sumberdaya alam.

Wilayah Pegunungan Seribu letaknya cukup jauh dari pusat kota Wonosari maupun kota Yogyakarta, hal ini mengakibatkan petani lebih dominan menggunakan aset fisik di bandingkan dengan aset yang lain seperti infrastruktur jalan untuk mendapatkan sarana dan prasarana produksi serta menjual hasil panen. Aset finansial menempati urutan kedua setelah aset fisik. Aset finansial merupakan ketersediaan dana baik dalam bentuk uang maupun tabungan di bank dan di tempat lain yang dapat dengan mudah digunakan untuk 
penghidupan, akses kredit, pendapatan dan sumber pembiayaan yang lain (Anonim, 1999; Scoones, 1998). Aset finansial sangat penting karena aset ini paling liquid di antara aset-aset lain, sehingga dapat langsung digunakan maupun dipertukarkan dengan aset-aset yang lain. Aset finansial dapat digunakan untuk membeli produk atau barang-barang konsumsi (Ellis, 2000). Keterbatasan infrastruktur dan lokasi yang jauh dari pusat kota mengakibatkan petani di Desa Jepitu harus mengeluarkan aset finansial yang lebih banyak dibandingkan di daerah lain.

Prioritas penggunaan aset selanjutnya adalah aset sosial. Aset sosial mempunyai pengaruh terhadap aset-aset yang lain, antara lain dapat meningkatkan efisiensi dari hubungan ekonomi sehingga biaya transaksi menjadi lebih sedikit yang selanjutnya berdampak pada peningkatan pendapatan (aset finansial). Aset sosial juga dapat mengurangi permasalahan kepemilikan barangbarang publik karena adanya jaringan dan kepercayaan. Jaringan sosial yang merupakan komponen dari aset sosial dapat memfasilitasi kreativitas dan pengembangan dan penyebaran pengetahuan (Anonim, 1999).

Beberapa cara yang dapat dilakukan untuk memperkuat aset sosial adalah dengan pemberdayaan kelompok/organisasi, meningkatkan fungsi kelompok melalui kemampuan kepemimpinan maupun manajemen. Penguatan aset sosial secara tidak langsung dapat dilakukan dengan membangun dan meningkatkan jaringan dengan pihak luar. Keberadaan aset sosial tergantung pada partisipasi individu dan anggota kelompok dalam jaringan sosial melalui komunikasi, pengetahuan dan dukungan yang diberikan (Ellis, 2000). Komunikasi, pengetahuan dan dukungan bagi petani dalam mengelola hutan rakyat sangat diperlukan karena menentukan persepsi petani terhadap hutan rakyat. Persepsi masyarakat terhadap hutan akan mempengaruhi bentuk-bentuk interaksi yang mempunyai dampak positif maupun negatif terhadap hutan (Kadir dkk., 2013; Raharjo dkk., 2013).

Dominasi aset selanjutnya adalah aset sumberdaya manusia. Sumberdaya manusia merupakan agen yang aktif untuk mengumpulkan aset, mengekploitasi sumberdaya alam, membangun hubungan sosial, ekonomi dan politik serta organisasi dan membawa pada perubahan di masa yang akan datang (Olaniyan dan Okemakinde, 2008). Aset sumberdaya manusia yang dimaksud dalam penelitian ini meliputi kesehatan, tenaga kerja keluarga, keterampilan dan pendidikan. Upaya yang dapat dilakukan untuk meningkatkan aset sumberdaya manusia adalah dengan meningkatkan akses terhadap pendidikan, informasi, teknologi dan pelatihan-pelatihan serta penyediaan sarana kesehatan dan terjaminnya suplai gizi (Anonim, 1999).

Pengembangan sumberdaya manusia sangat penting untuk dilakukan karena karena adopsi teknologi dan pengetahuan dalam pengelolaan hutan rakyat sangat tergantung pada kapasitas pengelolanya. Beberapa faktor yang mempengaruhi adopsi teknologi dalam pengelolaan hutan rakyat adalah sumberdaya manusia yang terkait dengan umur dan pendidikan. Umur kepala keluarga sangat mempengaruhi perilakunya terhadap adopsi teknologi. Petani yang mempunyai umur lebih muda akan lebih inovatif dan lebih terbuka terhadap teknologi baru. Umur merupakan karakteristik individu yang sangat berperan dalam menentukan kemampuan kerja dan produktivitas kerja (Handoko, 2001; Kadir dkk, 2012). Demikian juga dengan tingkat pendidikan, petani dengan pendidikan yang lebih tinggi cenderung lebih terbuka terhadap adopsi teknologi baru (Diggennaro, 2010)

\section{KESIMPULAN}

Pemetaan aset penghidupan menentukan bentuk-bentuk intervensi yang dapat dilakukan untuk meningkatkan peran hutan rakyat dalam penghidupan petani. Pemetaan aset divisualisasikan dalam pentagon diagram sehingga dapt dilihat aset yang paling dominan digunakan petani dan perbandingan antar aset. Pemetaan aset petani dalam mengelola hutan rakyat di Gunungkidul dibedakan dalam 3 zona (Pegunungan Baturagung, Ledok Wonosari dan Pegunungan Seribu) karena kondisi geomorlogi di setiap zona yang berbeda.

Petani hutan rakyat di zona Batur Agung (bagian utara Gunungkidul) menggunakan aset berdasarkan prioritasnya yaitu aset sumberdaya manusia, sosial, sumberdaya lama, fisik dan finansial. Urutan penggunaan asset petani di zona Ledok Wonosari (bagian tengah) adalah aset sosial, sumberdaya manusia, finansial, fisik dan sumberdaya alam. Bagi petani di zona Pegunungan Seribu prioritas penggunaan aset adalah aset fisik, finansial, sosial, sumberdaya manusia dan sumberdaya alam.

\section{UCAPAN TERIMAKASIH}

Penulis mengucapkan terima kasih kepada ACIAR dan Fakultas Kehutanan UGM yang telah mendanai penelitian "Overcoming constraint to community-based commercial forestry (CBCF) in Indonesia” FST/2008/030, di mana pemetaan aset penghidupan merupakan salah satu bagiannya. Kepada Digby Race diucapkan banyak terima kasih atas masukan selama penelitian ini berlangsung. 


\section{DAFTAR PUSTAKA}

Anonim, 1999. Sustainable Livelihoods Guidance Sheet. Department for International Development (DFID), London.

Awang, S.A., 2005. Prinsip Dasar Analisis Kelembagaan Dalam Usaha Perhutanan Rakyat, dalam Seri Nunga Rampai Hutan Rakyat: Petani, Ekonomi dan Konservasi. Aspek Penelitian dan Gagasan. Debut Press, Yogyakarta.

Diggenaro, S.W., 2010. Evaluation of the Livelihood Impact of a Micro-Irrigation Project in Zambia. Thesis. The Ohio State University. Ohio.

Ellis, F., 2000. Rural Livelihoods and Diversity in Developing Countries. Oxford University Press, Oxford.

Ethika, D., Purwanto, R.H., Senawi., dan Masyhuri, 2014. Peranan Petani Terhadap Strategi Pembangunan Hutan Rakyat di Bagian Hulu Sub DAS Logawa di Kabupaten Banyumas Jawa Tengah. Jurnal Manusia dan Lingkungan, 21(3):377-385.

Handoko, T.H., 2001. Manajemen Personalia dan Sumberdaya Manusia. BPFE, Yogyakarta.

Jakobsen, K., 2013. Livelihood Asset Maps: A Multidimendional Approach to Measuring Risk-Managment Capacity and Adaptation Policy Targeting- A Case Study in Bhutan. Regional Environment Change. (13):219-233.

Jele, Z., 2012. The Contribution of Small-Scale Timber Farming in Enhanching Sustainable Livelihood at Sokhulu. Thesis. University of South Africa. South Africa.

Kadir, A., Awang, S.A., Purwanto, R.H., dan Poedjirahajoe, E., 2012. Analisis Kondisi Sosial Ekonomi Masyarakat Sekitar Taman Nasional Bantimurung Bulusaraung, Provinsi Sulawesi Selatan. Jurnal Manusia dan Lingkungan, 19(1):1-11.

Kadir, A., Awang, S.A., Purwanto, R.H., dan Poedjirahajoe, E., 2013. Analisis Stakeholder
Pengelolaan Taman Nasional Bantimurung Bulusaraung, Provinsi Sulawesi Selatan. Jurnal Manusia dan Lingkungan, 20(1):11-21.

Krantz, L., 2001. The Sustainable Livelihood Approach to Proverty Reduction. Swedish International Development Cooperation Agency (SIDA), Stockholm.

Kusters, K., Belcher, B., Ruiz-Peres, M., dan Achdhiawan, R., 2005. A Method to Assess The Outcomes of Forest Product Trade on Livelihoods and The Environment. CIFOR Working Paper no. 32. CIFOR. Bogor.

Mendoza., 1999. Guidelines for Applying Multicriteria Analysis to The Assessment of Criteria and Indicator. CIFOR. Bogor.

Nurhadi, A., Setiawan, B., dan Baiquni., 2012. Kearifan Lingkungan dalam Perencanaan Dan Pengelolaan Hutan Wonosari Kecamatan Ngawen Kabupaten Gunungkidul. Jurnal Manusia dan Lingkungan, 19(3):226-237.

Nuraini, C., 2015. Kearifan Lingkungan dalam Pengelolaan Hutan, Tanah dan Sungai di Desa Singengu Kecamatan Kotanopan Kabupaten Mandailing Natal, Sumatera Utara. Jurnal Manusia dan Lingkungan, 22(1):100-205.

Olaniyan, D.A., dan Okemaninde, T., 2008. Human Capital Theory: Implication for Educational Development. European Journal of Scientific Research. 24(2):157-162.

Raharjo, S.A., Awang, S.A., Pramusinto, A., dan Purwanto, R.H., 2013. Sejarah Dominasi Negara Dalam Pengelolaan Cendana di Nusa Tenggara Timur. Jurnal Manusia dan Lingkungan, 20(1):1-10.

Salosa, S.T., Awang, S.A., Suryanto, P., dan Purwanto, R.H., 2014. Hutan dalam Kehidupan Masyarakat Hatam di Lingkungan Cagar Alam Pegunungan Arfak. Jurnal Manusia dan Lingkungan, 21(3):349-55.

Scoones, I., 1998. Sustainable Rural Livelihoods: A Framework for Analysis. IDS Working paper, 72. Brightons. 